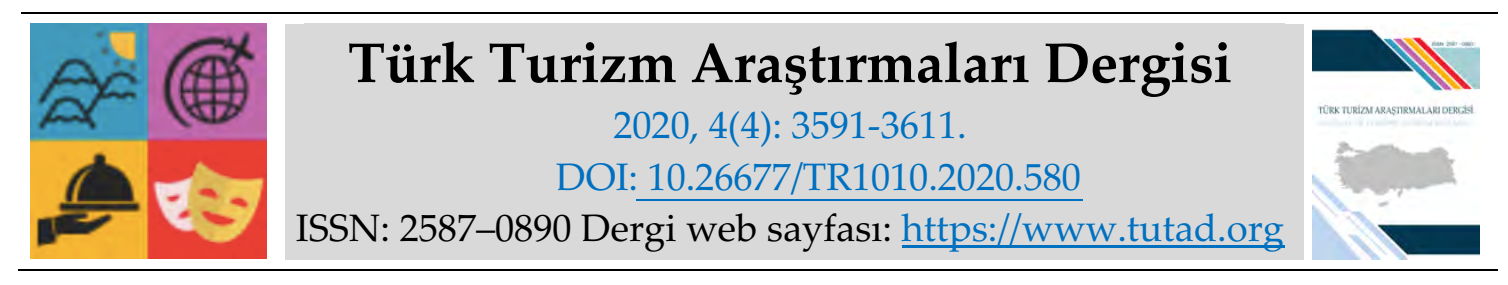

ARASTIRMA MAKALESI

\title{
Destinasyon Markalaşmasında Logo ve Amblemler: Ardahan Kent Örneği
}

Dr. Binali KILIÇ, T.C. Hazine ve Maliye Bakanlığı, İstanbul, e-posta: kilicbinali@gmail.com ORCID: https://orcid.org/0000-0001-8345-6617

$\ddot{O} z$

Kentler, insanlar için eşsiz ve biricik yerleşim yerleridir. Bu anlamda insanlar için her kentin farklı bir kimliği ve önemi vardır. Kentlerin bu kimlikleri öncelikle logo ve amblemlerde anlam bulurlar. Amblem ve logo tasarımları bir kentin görünen ilk yüzüdürler. Logo ve amblemlerin; destinasyonların bilinirliğini arttırmada, kimlik kazandırmada, tanıtımında, eşsizliğini, benzersizliğini ve seçkinliğini vurgulamada önemli roller üstlendiği bilinen bir gerçektir. Bu çalışmanın amacı, Türkiye'nin en önemli serhat kentlerinden birisi olan Ardahan kentinin destinasyon markası olma sürecinde logoların ve amblemlerin önemini ortaya koymaktır. Bu çerçevede, marka kimliğini yansıtan öz değerlerin Ardahan kenti destinasyonunda logo ve amblemlerin kullanılma durumunu araştırmaktır. Bu amaçla, Ardahan kentine ait 9 adet destinasyon yönetim örgütü olan kamu kurumu niteliğinde kurumların logoları incelenmiştir. Araştırma bulgularında; kurumların öz değerlere sahiplenme konusunda istekli oldukları gözlenmiştir. Ancak logoların anlaşılırlığı, sadeliği ve akılda kalıcılı̆̆ı gibi konularda yeterli olmadığı söylenebilir. Bu nedenle, destinasyon yönetim örgütlerinin logo tasarımlarında profesyoneller ile işbirliği yapmaları önerilmektedir.

Anahtar Kelimeler: Ardahan Kenti, Destinasyon Markalaşması, Kentsel Logo ve Amblemler Makale Gönderme Tarihi: 05.06.2020

Makale Kabul Tarihi: 09.10.2020

\section{Önerilen Atıf:}

Kılıç, B. (2020). Destinasyon Markalaşmasında Logo ve Amblemler: Ardahan Kent Örneği, Türk Turizm Araştırmaları Dergisi, 4(4): 3591-3611.

(C) 2020 Türk Turizm Araştırmaları Dergisi. 


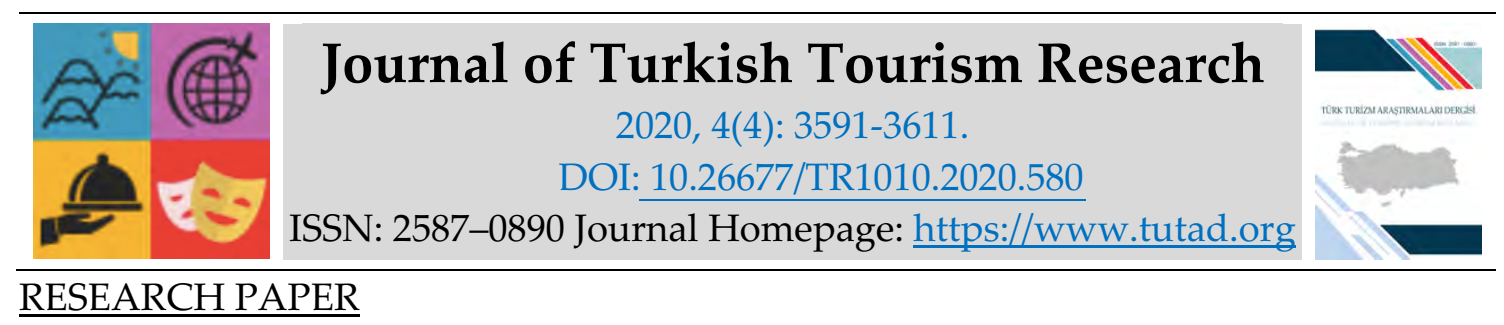

Logos and Emblems in Destination Branding: A Sample of Ardahan

Dr. Binali KILIÇ, Republic of Turkey Ministry of Finance and Treasury, İstanbul, e-mail: kilicbinali@gmail.com

ORCID: https://orcid.org/0000-0001-8345-6617

\begin{abstract}
Cities are unique and unexcelled places for people. Every city has different identity and value in this sense. The identity of the cities becomes meaningful with their logos and emblems. Logo and emblem designs are the first exposed faces of the cities. It is a known fact that logos and emblems enhance the recognition of the destinations, create their identity and highlight the publicity, uniqueness, specialness and excellence of the cities. The aim of this research is to exhibit the importance of the logos and emblems during the becoming of Ardahan which is one of the most important border cities of Turkey as a destination brand. Within this framework the other aim of this research is to analyze the usability of logos and emblems in Ardahan destination in core values reflecting brand identity. For this purpose, logos of 9 destination managing organizations having the characteristics of public corporation in Ardahan have been analyzed. Research findings showed that; organizations are eager to protect the core values. Nevertheless, it can be said that understandability, simplicity and memorability of logos are insufficient. As a consequence, it is recommended for the destination managing organizations to work with professionals in their logo designing process.
\end{abstract}

Keywords: Ardahan, Destination Branding, Urban Logos and Emblems.

Received: 05.06.2020

Accepted: 09.10.2020

\title{
Suggested Citation:
}

Kılıç, B. (2020). Logos and Emblems in Destination Branding: A Sample of Ardahan, Journal of Turkish Tourism Research, 4(4): 3591-3611.

(C) 2020 Türk Turizm Araştırmaları Dergisi. 


\section{Gíriş}

İnsanlar gibi kentlerin de kendine özgü kimlikleri vardır. Kentlerin bu kimlikleri kendilerini diğer kentlerden ayırt etmeye yarar (Görgülü, 2019: 66). Bu çerçevede her kent kendisini diğer kentlerden ayırt eden özelliklerini ön plana çıkarmaya çalışır.

Turizm, ülkelerin hedeflemiş olduğu ekonomik refaha ulaşmada önemli bir iktisadi rolü bulunmaktadır. Ancak bu iktisadi rol, turizm potansiyelinin doğru bir anlayış ve bakış açısı ile yürütülmesi sonucunda başarıya ulaşabilmektedir. Turizmin iştah kabartan geliri nedeniyle tüm dünyada ülkeler ve kentler düzeyde destinasyon pazarlamasına ağırlık verildiği görülmektedir (Tür, 2018: 11). Nitekim kentler bulunduğu coğrafyadan bağımsız değildir. Üstelik bulunduğu coğrafyanın tüm kimlik özelliklerini taşırlar. Kentler bir bakıma kendisi ile ilgili görsel ögelerin insan zihninde bıraktığı izler ile bütünleşirler (Belge, 2018: 168).

Tüketim toplumlarında, kentlerin kimliklerini yansıtan amblemin akılda kalıcı olması çok önemlidir. Tüketiciler haz, mutluluk ve sosyal statü edinme gibi nedenlerle de sembolik tüketimi önemsedikleri bilinen bir gerçektir (Esmeray, 2018: 2).

Logo ve amblemlerin destinasyonun bilinirliği, tercih edilebilirliği ve markalaşmasındaki etkisi ise çoktan fark edilmiştir. Turizm gelirlerinde istediği payı almak isteyen destinasyon yönetim örgütleri ve paydaşları kullandıkları logo ve amblemler ile de tüketicilerin zihninde destinasyon markası yaratmaya çalıştıkları bilinen bir gerçektir. Örneğin; Pizza İtalya'yı, Piramitler Mısır'ı, Çin Setti Çin'i çağrıştıran simgelerdir.

Türkiye'nin en önemli Serhat kenti olan Ardahan, tarihi geçmişi, doğası, endemik bitki örtüsü, Kafkas arı ırkının en iyi çiçek balı, kaşar peyniri, kazı, atlı kar kızakları, içi ve dışı kırmızı olan Posof elması, Çıldır gölü ve Yalnızçam kayak tesisleri ile gastronomik açıdan giderek gelişen iç ve dış turizm destinasyonu olma yolunda yerel halk ve yerel yöneticilerin çabaları bulunmaktadir.

Dünyada destinasyon markası çalışmalarında logo ve amblemlerin önem kazandığı görülmektedir. Bu nedenle Ardahan kentine ait logo ve amblemlerin destinasyon pazarlaması açısından içerik analizi yapılması amaçlanmıştır

Ardahan kenti destinasyonu yerel değerlerin, doğanın, endemik bitki örtüsünün, kültürün ve mitolojik öykülerden esinlenerek oluşturulan, logo ve amblemlerin kenti akılda kalacak şekilde farklılaştıracağı düşünülmektedir. Gelişen ve cazip bir destinasyon olma yolunda olan Ardahan kentinin sahip olduğu yerel değerlere ait logo ve semboller ile mitolojik imgelerin destinasyon pazarlaması yönünden farkındalığını araştırarak, konunun önemine ve Ardahan kentine yönelik farkındalık yaratmak amaçlanmıştır.

$\mathrm{Bu}$ açıdan gelişmekte olan Ardahan kenti turizm destinasyonunun araştırma evreni olarak seçilmesine karar verilmiştir. Söz konusu çalışma ile, Serhat Ardahanlı hemşerilerine, turistik seyahate katılanlara, turizm alanındaki akademik çalışmalara, destinasyon yönetimi organizasyonlarına, kentin yöneticilerine, Sivil Toplum Kuruluşlarına ve yerel halkın bilgilenmesine katkı sunacağı gibi farklı açılımlar kazandıracağı düşünülmektedir.

\section{KAVRAMSAL ÇERÇEVE}

İnsanoğlunun yerleşik hayata geçmesiyle birlikte medeniyetler oluşturulmuştur. Bu medeniyetler birbirlerinden ancak nesneler üzerindeki çeşitli işaret ve semboller ile ayırt edilebilmişlerdir. Ticaretin gelişmesi ile bu işaret ve semboller ürünün kime ait olduğunu göstermek amacıyla kullanılmaya başlanmıştır. Bu da markaların oluşmaya başlamasına neden 
olmuştur. Bu çerçevede değerlendirildiğinde toplum geliştikçe ve değişime uğradıkça logo, amblem, sembol ve slogan gibi marka kimliklerinin güncellenmesi veya dönemin yapısına göre şekillenmesi önem taşımaktadır (Toy, 2020: 175). Uygarlığın M.Ö. 3500 yıllarından itibaren hızla geliştiği Sümer'de ve Mısır'da düşünceyi ifade eden resim-yazının ilk örnekleri görülmektedir. Buna örnek olarak, öküz ifade edilecek ise öküz başını gösteren basit bir resim veya çizik aynı zamanda bir kelime yazısı olarak düşünülmüştür (Çalış, 2019: 33). Görüleceği üzere, kentlerin logoları ve amblemleri; kentlerin imajını, kimliğini ve tanıtımını yaparak kentlerle özdeşleşen en önemli yazılı ögelerdir (Bilirdönmez ve Şahin, 2019: 39).

Logo ve amblem ülkelerin, kentlerin, kişilerin ve şirketlerin kimliğini ifade etmekle kalmayıp insan zihninde kalıcılığı sağlayan en önemli araçlardan birisidir. Bu özelliğinden dolayı dünyaya açllan pencere görevini gören kentlerin ve kurumların logo ve amblemini analiz etmek büyük önem taşımaktadır (Çakır, 2013: 54). Ülkeler, kentler, şirketler ve kişilerin markalanmasının temel amacl; zihinde güçlü pozitif izlenimler bırakmak, hedef müşteri kitlesine kolayca ulaşmak ve onları ikna etmektir. Bu çerçevede kurumsal kimliğin oluşturulması, tasarlanması profesyoneller ile birlikte çalışmayı gerektirir (Köse, 2020: 190).

Kentlerin de insanlar gibi kendine özgü kimlikleri vardır. Böylece diğer kentlerden ayırt edilebilirler. Bu nedenle kentlere kimlik kazandırma süreci her zaman önemli bir konu olarak tüm paydaşların gündeminde yer almaktadır (Görgülü, 2019: 66). Bir kente kimlik kazandırma ancak; Logosu, amblemi, tarihi ve kültürel yapısı, doğası, kahramanlıkları, hikâyeleri ve mitolojisi ile kazandırılır.

Turizm, ülke, kent ve toplum kalkınmasında önemli araçlardan biri olarak kabul edilmektedir (Serçek ve Hassan, 2016: 7). Tüketicinin etkilenebilmesi için nitelikli görsel kimliklere her zaman ihtiyaç vardır (Bayraktaroğlu ve Çalış, 2011:5). Tüketiciler tercih ettikleri destinasyonu birçok rakip veya alternatifler arasından yapmaktadır (Yenipınar ve Yıldırım, 2016: 29). Bu açıdan incelendiğinde, turistik destinasyonların tercih edilmesinde sürdürülebilir turizm politikası dâhil birçok faktör yer almaktadır. Bu faktörler misafirlerin tercihlerini etkilemektedir (Çiçek ve Ilgaz, 2015: 171). Küreselleşme veya göç nedeniyle şehirlerin çok büyük çevre kirliliği ile yaşanamaz hale geldiği görülmektedir (Acar, 2018: 46). Bu nedenle sürdürülebilir turizm çerçevesinde destinasyonların markalanması için bu kaygı verici çevre kirliliğine karşı gerekli tedbirler alınmalıdır. Bu tedbirler ile birlikte kentin logosu ve amblemi ile bu durum insanların zihninde yer edinecek şekilde tasarlanabilir.

Destinasyon pazarlaması ile ülkelerde, kentlerde ve firmalarda çok önemli sosyal, ekonomik ve kültürel değişim meydana getirilebilmektedir (Unur ve Çetin, 2017: 63). Ürünlerin ve hizmetlerin çekiciliğini arttırmak ve görsel kimliklerini kazanması için amblem kullanılmaktadır. Amblem markanın görsel kimliği olduğundan çoğu zaman marka isminden daha çok zihinde kalmaktadır. Çoğu zaman markanın amblemi, markanın kalitesinin önüne geçtiği görülmektedir (Kahraman, 2012: 108).

\section{DESTINASYON MARKASI OLUŞUM SÜRECI}

Marka kent olma ancak stratejik bir süreç ile mümkündür. Bu süreç iç ve dış paydaşlar ile birlikte yürütülür. Bu stratejik sürecin en önemli aşaması kent ile ilgili tüketici zihninde kalan bir imaj yaratmaktır (Görgülü, 2019: 68). Destinasyon, gidilecek yer ve varılacak hedef anlamına gelmektedir. Coğrafi açıdan ise, turistin ziyaret ettiği veya ziyaret etmeyi planladığı ülke, bölge, kent ve yer olarak tanımlanabilir (Köşker vd., 2020: 350).

Marka; ürün veya hizmeti tanıtan ve rakiplerinden ayıran simge, sembol, tasarım, isim, sözcük, işaret şekil, logo, amblem ve renk bileşiminden oluşan bileşimlerdir (Kahraman, 2012: 108). 
Kentler ile ilgili birçok değerler destinasyon pazarlamasına konu olabilir (Yenipınar ve Yıldırım, (2016: 29). Markalaşma firmanın beklentileri doğrultusunda sonuçlanabilmektedir. Diğer bir deyişle ürün veya hizmetin değeri marka stratejisi ile birlikte artmaktadır.

Bir markanın değer artışı; doğru amblem, doğru reklam kanalları ve gerçek tüketici grubu ile birleşince olumlu sonuçlar elde edilebilmektedir (Kahraman, 2012: 109). Destinasyon markalamasını, destinasyonun ayırt edici özelliklerini ön plana çıkaran kimlik oluşturma süreci olduğu söylenebilir (Unur ve Çetin, 2017: 64). Markalaşma ise, ülkeye, kente ve firmaya ait markayı benimsetme ve bağllı̆̆ını artırma sürecidir. Bu süreç tamamen bir seçim stratejisi ile sonlanır (Zeybek, 2019: 1327). Kent markası oluşturmak ve markalama sürecini yönetmek için, kentlerin öne çıkan özellikleri ve değerleri ortaya çıkarılmalıdır. Bu çerçevede logolar ve amblemler ile kentin en güçlü değerleri yansıtılmalıdır. Böylece logo ve amblemler kentin görsel kimliklerini yansıtan değerler olarak ortaya çıtığı söylenebilir (Görgülü, 2019: 66).

Dünyada ilk destinasyon pazarlamasının 1850'li yıllarda Amerika'da ve 1900'lü yıllarda ise İngiltere ve Fransa'da başladığı görülmektedir. Bununla birlikte 21.yüzyılın ilk çeyreğinde dünyadaki turizm hareketlerinden daha fazla pay almak isteyen ülkeler ve kentler destinasyon pazarlamasına yönelik çalışmalarını hızlandırmışlardır. Bu da kentlerin gelişmesine neden olmakla birlikte birçok değişimi ve yenileşmeyi beraberinde getirmektedir (Köşker vd., 2019: 349). Şehirlerin destinasyonuna yönelik pazarlamanın 19. yüzyıldan beri uygulandığ bilinmektedir. Kentin bir destinasyon olarak pazarlanmasının başında markalaşma süreci gelmektedir. Markalaşma ile kent kimliği daha fazla ön plana çıkmaktadır. Ayrıca kentin destinasyon pazarlanması yerini kent markalaşmasına bıraktığı gözlenmektedir (Köroğlu ve Yağc1, 2018: 64). Günümüzde rekabetin yoğun olduğu tüm alanlarda olduğu gibi markalı turizm destinasyonları yaratmanın kolay olmadığı söylenebilir (Aslan, 2014: 4).

Pazarlanabilme ve olumlu imaja sahip olmak sadece mal ve hizmetler için değil, ülkeler ve kentler için de önemli bir geçerlilik kazandığı görülmektedir (Özerk ve Yüksekli, 201: 82). 20. yüzyılın ikinci yarısından sonra post-modern kültür koşullarında markaların; tüketicilerin sembolik, duygusal, politik ve kültürel yollar ile ilgisini çektiği görülmektedir. Küresel dünyada marka; kentleri, firmaları ve kişileri ulusal ve uluslararası pazarda görünür yapan önemli araçlardan birisidir (Nas, 2017: 202). 21. yüzyılda turistik markalar, rakiplerini izlemeli, ürün ve hizmetlerini farklılaştırmalıdır. Böylece belli bir pazara odaklanarak, müşterilerin pazarlık gücünü güçlü marka değeri ile zayıflatabilirler (Kılıç ve Uslu, 2019: 96).

Serçek ve Hassan (2016: 9)'a göre, bir kentin turistik destinasyon olmasının şu yararları vardır. Turistik bölgenin rakiplerinden ayırt etmesini sağlar, ziyarete karar verme aşamasında tereddüt riskini azaltır, turistik destinasyonun ve ülkenin sembolü işlevini görür, turistik destinasyonun markalanması, kente ait ürünlerin de markalanmasını hızlandırır, destinasyonlara tekrarlı gelişlere sebep olur ve böylece sadık müşteri potansiyeli oluşturulur.

\section{DESTINASYON MARKALAŞMASINDA LOGO ve AMBLEMİN ÖNEMİ}

Logo ve amblem ayn kavramlardır. Ancak, amblem sözcük özelliği olmayan soyut veya nesnel görüntülerden oluşur (Esmeray, 2018: 2). Ceylan (2016:318)'a göre ise; Amblem ve logo kavramları birbirinden farklı kavramlardır. Amblemde kentin ve/veya firmanın adı yer almazken, logo ile sadece kentin ve/veya firmanin adı ile oluşturulabilmektedir. Amblemler logo ile birlikte kullanılırlar. Amblem şekil ve harflerden oluşmakla birlikte, logolar isimlerin tipografik düzenlemelerinden oluşur.

Marka kentlerin kimliği renkler, logolar, amblemler, sloganlar, grafik ve semboller ile ortaya çıkarılarak hedef kitle tarafından tanınması sağlanır (Görgülü, 2019: 68). Rekabet ortamında ve 
tüketici tercihinde destinasyonu belirleme sürecinde temel unsur o destinasyonun sahip olduğu turistik çekiciliklerdir (Köşker vd., 2020: 343). Günümüzde ülkeler, bölgeler, kentler, yöreler, firmalar, STK'lar ve kişiler kurumsal kimlik göstergesi özelliğinden dolayı kendisini en iyi anlatan logo ya da amblem oluşturma yarışındalar (Özderin, 2019: 196). Görüleceği üzere destinasyonlar ve hatta köyler markalaşmaktadır. Markalaşma; ülkeleri, bölgeleri, kentleri, üretilen mal ve hizmetleri tüketicinin zihninde en güçlü şekilde tanımlayan ve onları rakiplerinden ayırt etmeye yarayan isim, terim, işaret, logo, sembol, amblem ve şekillerdir (Serçek ve Hassan,2016: 8). Markalaşmanın ilk aşamalarından birisi tüketicilere yönelik amblem veya logo analizidir (Köçker vd., 2020: 351).

Logolar, amblemler vb, kent kimliklerini simgelemektedir. Kent kimliği bir kenti diğerlerinden ayran birçok özellik ile kendini farklılaştırır. Bu farklılaşma logolardaki ve amblemlerdeki vb. sembollerle anlatılmaya çalışılır (Aliağaoğlu ve Uğur, 2018: 2363). Aidiyeti dillendiren, görsel kimliklerin başında amblem ve logo simgeleri gelmektedir (Bayraktaroğlu ve Çalış, 2011: 7). Serçek ve Hassan'a (2016: 13) göre, turizmde destinasyon markalaşmasında slogan, logo, sembol gibi, görünmeyen değerlerine yatırım yapılmasının gerektiğini belirtmişlerdir.

Destinasyonlar basit bir ürün gibi düşünülerek pazarlanamazlar. Bu nedenle destinasyonlar birçok konuda farklılaşarak benzersiz bir marka oluşturmalıdır. Destinasyon markalamasında, destinasyon kimliği ve destinasyon marka imajı en önemli faktörlerdir (Unur ve Çetin, 2017: 66). Destinasyonlar karmaşık yapılarından dolayı yönetilmesi ve pazarlanması en zor olan turistik üründür (Morçin ve İşler, 2017: 1082). Pazar konumlandırma genellikle bir marka adı, logo, amblem ve slogan gibi sembolleri içerir (Morçin ve İşler, 2017: 1082). Destinasyonun marka kimliği, sadece bölgenin tarihi, kültürel ve doğal özelliklerini içeren boyutları değil, yerel gelenekler ve ögeler içeren bu boyutlarda, destinasyonu farklılaştırmaktadır (Yenipınar ve Yildırım, 2016; 30).

Destinasyonlar başarılı olmak için rakiplerinden farklılaşarak bölgedeki kültürel, tarihi ve doğal ögelere odaklanmaları gerekmektedir. Bu açıdan destinasyon markası yerel bir simge, mitolojik bir figür, bir logo ve amblem olarak kimlik kazanır (Yenipınar ve Yıldırım, 2016; 31). Bu bağlamda destinasyon pazarlaması ve markalaması için kentteki tüm kuruluşlar ve paydaşlar, ulusal ve uluslararası platformda tüketicilere kendilerini anlatmak için görsel kimlik unsurlarından amblem ve logo tasarımlarında, "insan zihninde kalıcılık" ve "süreklilik" oluşturacak şekilde oluşturulması beklenir (Bayraktaroğlu ve Çalış, 2011: 4).

Destinasyonların markalaşması ile yerli ve yabancı marka zincir otel işletmeleri, küresel pazarlardan pay alabilmek için destinasyondaki yerel işletmeler ile stratejik işbirliğine girdikleri görülmektedir (Kılıç ve Uslu, 2019: 214). Bu stratejik işbirliği, konaklama işletmeleri yatırımı, franchise verme vb. şeklinde olabilmektedir. Ayrıca yerli ve yabancı marka zincir otellerin destinasyon bölgesine yatırım yapmaları destinasyonun marka değerini arttırdığı söylenebilir.

Destinasyon pazarlamasında en etkili araç markalama olduğu bilinen bir gerçektir. Logo, amblem ve sloganlar destinasyonun marka kimliğinde dikkate alınmalıdır. Bu açıdan kentlerin logo ve amblemleri özgün, ayırt edici olmalı ve kentin gerçek imajını yansıtmalıdır (Köşker vd., 2020: 350). Şehirler, deneyimler ve anlamlar bütünüdür. Bu deneyimler ve anlamlar logo ve amblem ile görselleştirilir (Aliağaoğlu ve Uğur, 2018: 2358). Kente ait mitler, kuşaktan kuşağa aktarımı sadece sözcüklerle aktarılmaz. Taşa atılan bir çentik veya ağaç dalına çizilen bir yarık ve bunların yorumlanabilmesine "yazı" dememizi gerektirir. Bu açıdan semboller yazı kadar anlamlı ve yüklü manalar taşırlar (Çakır, 2013: 55).

Kentlerin markalaşması sürecinde, markalaştırılacak kentler için logo ve amblem oluşturulması kaçınılmazdır. Kentin iç ve dış turizmde markalaşmasında, tanıtımında ve pazarlamasında, kültürel, mitolojik ve doğal zenginliklere dikkat çekmek amacıyla resmi bir logo benimsenmesi 
kentler açısından çok önemlidir (Köroğlu ve Yağcı, 2018: 64). Şu bir gerçek ki; kentlerde paydaşlar ile birlikte yürütülen sosyal, kültürel, sanatsal, ulusal ve uluslararası projeler kentin markalaşmasına katkı sağlamaktadır (Demir, 2018: 1576).

Logo ve amblem kentin görsel kimliği, kurumsallığını ve marka kimliğini temsil eder. Bu nedenle, grafik tasarımı açısında özel bir öneme sahiptir (Özderin, 2019: 198). Markalaşarak, pazar payını elde etmek için; ülkenin, bölgenin, kentin, firmanın veya kişinin ihtiyaç duyduğu temel şey kimliktir. Markaya yüklenen kimlik, pazardaki rekabet gücünü etkilemekte ve rakiplerinden farklı olmaktadır (Kahraman, 2012: 109). Görsel kimlik tasarımları nitelikli, kolayca tanınabilir, zihinde kalıcı olacak şekilde tasarlanmalıdır (Bayraktar ve Çalış, 2011: 9). Amblem ve logo, markaların temel amacı olan tüketici zihninde kalıcı olmaya odaklanır (Keş ve Yıldız, 2018: 72).

Logo, bir ülkenin, kentin, firmanın, ürünün vb. isminin harf ve resimsel öğeler kullanılarak sembolleştirilmesidir. Amblemden farklı olarak logo ismi yansitır (Demir ve Tür, 2019: 54). Logo, bir markanın görsel ögesidir. Tüketici ile ürün/hizmet arasındaki en önemli köprü logodur. Logo tasarlayanın hayalindeki şekilden ibaret olmayıp, özel analizlerin, renklerin, çeşitli işaret ve sembollerin uyumlu bir karışımıdır (Ayıc1, 2020: 23). Markada logo kullanımı görsel algı açısından önemli bir araçtır (Keş ve Yıldız, 2018: 71).

Kent logolarının özellikleri şu şekilde sıralanabilir: Kentin en dinamik yapısını ortaya çıkarır, kent imajı yaratır, kentin en önemli değerini sembolize eder, kentin görünmeyen değerinin ortaya çıkarılmasını ve kent kimliği ile bütünleşmesini sağlar, kent ile ilgili iç ve dış paydaşlar arasında stratejik bir iletişim sağlar ve kente ilişkin alg1 oluşturur (Görgülü, 2019: 75).

AEG (Allgemeine Elektrizitäts-Gesellschaft) firması ilk kurumsal kimlik çalışması için logo 1899 yılında Otto Eckmann tasarlamıştır (Bayraktar ve Çalış, 2011: 10). Farklı anlamlara gelen bir veya birden fazla sembol bir araya getirilerek kentlerin logoları oluşturur. Logolar, kentlerin kimliklerini ve çevrenin coğrafi özelliklerini yansıttı̆̆ bilinmektedir. Özellikle, Valilik ve belediye gibi kamu kurumların logoları yerel kültürlerin özelliklerini yansitırlar. Logolarda yer alan semboller, kente ait birçok fikir verir (Belge, 2018:173).

Logo, kenti öyküleyen çok önemli bir araçtır (Köçker vd., 2020: 351). Logolar, markaların müşteriyle iletişime geçtiği en önemli satış, pazarlama ve tanıtım araçlarından birisidir (Toy, 2020: 178). Logo, kurumsal kimliğin bir bileşeni olarak markaların kalitesi ve marka gücü hakkında bilgi verir (Deneçli, 2015: 321). Marka ve logo arasında doğru bir ilişki vardır. Markanın ayırt edici özelliğinden biriside logodur. Logo aynı zamanda kent ve kuruluşların kültür ve değerlerini temsil eder (Demir ve Tür, 2019: 52). Belediye logoları ise, birçok coğrafi unsuru içinde bulundurmalıdır (Bilirdönmez ve Şahin, 2019: 39).

Köroğlu ve Yağcı (2008: 65)'ya göre, logoda şu özelliklerin bulunması gerekmektedir. Bunlar: markayı ve marka kimliğine güçlü bir vurgu yapmalı, sade, kolay tanınabilir, kolay hatırlanabilir olmalı, tek bir renge veya birden çok renge yer verilebilir, farklı şekillerde yapılabilir, istenilen mesajı çok net bir şekilde verilmeli ve kolayca okunacak yazı tipi seçilmelidir.

Markanın müşteri tarafından zihinde kalıcılığına hizmet eden en önemli işaretlerden biri de resimsel sembol olan amblemdir. Amblem, sözcük özelliği olmayan, soyut ya da nesnel görüntü veya harflerle oluşturulan çizgi ve resimle yapılan sembol ve simgelerdir (Kahraman, 2012: 110). Amblem, tüketiciler tarafından zihinde hızlıca ve devamlı bir şekilde kalması için ancak doğru tasarım ve simgeler ile mümkündür. Amblem, etkili bir görsel ifade oluşturarak markanın bilinirliğini güçlendirir (Esmeray,2018: 2). 
Amblem, logo ile birlikte kullanılabilen bir simgedir (Yenipınar ve Yıldırım, 2016; 32). Yenipınar ve Yıldırım (2016; 32)'a göre; markanın görsel temsilcisi olan amblem ve logo genel çerçevede belli başlı kabul görmüş özellikleri içeriyor olması gerekir.

Amblem, markaların vitrinleridir. Çünkü tüketici ilk aşamada ürün veya hizmetin amblemiyle karşılaşmaktadır. Bu nedenle, marka yönetimi sürecinde en önemli aşamalardan biri markaya uygun çizgiler, karakterler ve renklerin oluşturulmasıdır. Böylece hedef tüketicinin bilinçaltına psikolojik enformasyonlar gönderilebilir (Kahraman, 2012: 111). Şekil ve işaretlerin sözcüklere nazaran zihinde kalıcılığından dolayı, amblemler, tek bir simgeyle birçok anlamı sunmayı hedeflemelidir (Demir ve Tür, 2019: 52).

Amblemde yazı ölçütü: İnce çizgili uzun ve dar harfler zariflik vermektedir. Çizgisiz yuvarlak ve geniş harfler samimi, sempatik görünmektedir. El yazısı karakterleri, daha güvenilir, alçak gönüllü bir imajı ima eder. Büyük harfler ise oldukça otoriter, güçlü ve bazen de agresif bir imaj verebilmektedir. Küçük harfler ise cesareti ve alçak gönüllüğü simgelediği düşünülmektedir (Yenipınar ve Yıldırım, 2016: 32).

Amblemde şekil ölçütü: Köşeli veya dörtgen şekiller erkekliği çağrıştırırken, yuvarlak ve kavisli şekiller yumuşak olgulara çağrışım yapmaktadır. Simetri, dengeli görünüm ile güven hissi uyandırmakla birlikte, zaman zaman göze sıkıcı gelebilmektedir. Ayrıca simetri bir düzen ve sistem oluşturarak sakinlik verir. Asimetriğin fazlası gerginlik oluşturur. Hafif asimetri görselliğe özgünlük katar ve monotonluktan uzaklaştırarak çekicilik sağlar. Uzun, geniş, büyük şekiller güçlü ve etkili olarak algılanırlar. Bunun aksine küçük veya ince şekiller nazik, zarif veya zayıf olarak algılanırlar. (Yenipınar ve Yıldırım, 2016: 32).

Üçgenin, kendi içindeki yol gösterici özelliği vardır. Aynı zamanda tabanı yüzeye paralel olan üçgen denge hissi vermektedir. Kare, taşınmaz mülk ve yaşam anlamını katmaktadır. Ayrıca kısıtlama olarak algılanır. Daire ise başlangıç ve sonu olmayan sonsuzluğa çağırışım yapar. Bununla bitlikte; öncelik ve sonralık ile dünyanın ve güneşin sembolü olarak da değerlendirilmektedir (Ceylan, 2016: 316).

Amblem tasarımlarında siyah zemin üzerinde beyaz, beyaz zemin üzerinde siyah lekeler daha iyi sonuç alınmaktadır. Geometrik biçimler tasarımı kolaylaştırmaktadır. Tasarımın orijinin yazıyla bütünleşmesi tercih edilmelidir. Amblem ilgili olduğu kurum ve/veya kuruşun sembolü olduğundan gerçek faaliyet alanını yansıtmalıdır (Ceylan, 2016: 317).

Genel anlamda iyi bir logo ve amblem ise şu özelliklere sahip olmalıdır: İlgili kurumun, mal veya hizmetin özelliklerini yansıtmalıdır. Kesinlikle özgün olması gerekir. Renkler ve biçim olarak bir bütünlük sağlamalıdır. Okunabilir ve anlaşılabilir olmalı, gereksiz işaret, çizgi ve resimlere yer verilmemelidir. Harf adedinin fazlalığı ile okunurluk bozulmamalıdır (Gemci vd., 2009: 110). Hazırlanan amblem başka bir amblemi çağrıştırmamalıdır (Milli Eğitim Bakanlığı, 2012: 6).

\section{ARDAHAN KENTININ TURISTIK, GASTRONOMIK ve EKONOMIK ÜRÜNLERİ}

Ardahan kentinin coğrafi konumu, logo ve amblemlerinde yer alabilecek turistik, gastronomik ve ekonomik ürünler aşağıda açıklanmaktadır.

Ardahan kentinin coğrafi konumu Şekil 1'de gösterilmiştir. 


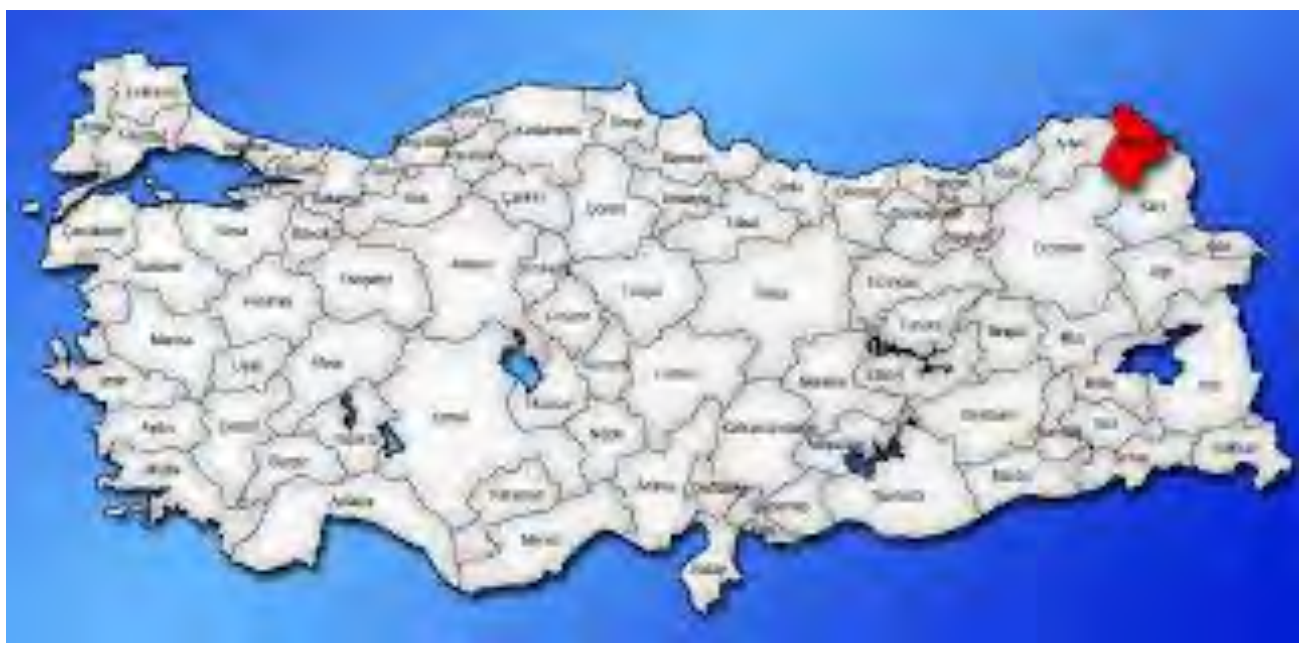

Şekil 1: Ardahan Kentinin Türkiye Coğrafi Haritasındaki Yeri

Kaynak: http://www.vizyonardahan.com/kent-profili/ardahan

Ardahan kenti, Türkiye'nin kuzeydoğusunda yer almaktadır. Güneydoğu ve güneyinde Kars, güneybatısında Erzurum ve batıda da Artvin ili bulunmaktadır. Kuzeyinde Acaristan Özerk Cumhuriyeti, Kuzeydoğusunda Gürcistan ve kısmen de Ermenistan ile sınırı bulunmaktadır (http://ardahan.gov.tr).

Atatürk Silueti; Ardahan'ın Damal ilçesinde doğal mucize olarak nitelendirilen Ulu Önder Mustafa Kemal Atatürk'ün silueti, her yıl 15 Haziran - 15 Temmuz tarihleri arasında ortaya çıkıyor. Siluet havanın güneşli olması durumunda her gün 17.55- 18.10 saatleri arasında izlenebiliyor. $\mathrm{Bu}$ doğaüstü durum her yıl temmuz ayında "Atatürk'ün İzinde ve Gölgesinde Damal Şenlikleri" ile kutlaniyor (www.haberler.com).

Ardahan'daki Kiliseler; Ardahan kenti birçok kavimlere ev sahipliği yapmıştır. Bu nedenle birçok etnik gruplara ait mimari ile karşılaşmak mümkündür. Kültür mozaiği denilince ilk akla gelmesi gereken kentlerimizden birisi olan Serhat Ardahan'ın dört bir yanında ve özellikle tepelerde kiliseleri mevcuttur ( (www.serka.gov.tr).

Ardahan Kuş Gözlemi Alanları; Ardahan kenti yaban hayat gözlemcileri için önemli bir duraktır. Ardahan göçmen kuşlar, endemik bitkiler, böcekler gibi birçok canlıya ev sahipliği yapmaktadır (www.serka.gov.tr).

Ardahan Kalesi; Ardahan Kalesinin Selçuklular tarafından yapıldığı ve Osmanlılar döneminde kullanıldığı bilinmektedir. Kalenin kapısı üzerinde Arapça bir kitabe bulunmaktadır. Kitabede "Arap, Rum ve Acem ülkelerinin deniz ve karalarının sahibi padişahlar padişahı Selim Han'ın oğlu Sultan Süleyman-ı Azam namına yapılmıştır. Mülkü kıyame kadar baki kalsın." yazmaktadır (www.ardahan.gov.tr).

Ardahan Yalnızçam Kayak Tesisleri; Doğu Anadolu, Karadeniz ve Kafkasların buluşma noktasında yer almaktadır. 6 pistin toplam uzunluğu 15 kilometrenin üzerinde 5 bin metre uzunluğunda pist uzunluğu vardır (www.ardahan.gov.tr).

Çıldır Gölü; Rakımı 1950 metre olan Çıldır Gölü'nün yüzeyi kış aylarında buzla kaplanmaktadır (www.ardahan.gov.tr). Çıldır gölü doğal set gölüdür (http://cildir.gov.tr). Turistik Doğu Ekspresi treni ile yapılan destinasyon da önemli bir merkezdir. Burada, göl üzerinde atlı kızakla gezinti yapılabilmektedir. Ayrıca, donmuş gölün içinde balık avlanabilmektedir. Turistlere, atlı kızak sürüş deneyimi ve buzda balık avlanma deneyimi yaşatmaktadır. 
Aktaş (Hozapın) Gölü; Yüksekliği 1794 metre olan göl sodalıdır. Gölde devamlı hareket halinde bulunan 12 küçük ada bulunmaktadır (www.ardahan.gov.tr).

Kura Nehri; Yurdumuzda Doğu Anadolu Bölgesi'nden doğup Azerbaycan topraklarında Aras ırmağı ile birleşerek Hazar Denizi'ne dökülmektedir (www.ardahan.gov.tr).

Endemik Bitki Örtüsü; Ardahan kentinde 300'e yakın bal bitkisi ve 25 endemik tür olmak üzere 2000 tür flora bulunmaktadır. Ayrıca dünyadaki dört önemli arı ırkından biri olan Kafkas Arı ırkının gen merkezidir (www.tarimorman.gov.tr).

Ardahan Yaban Hayatı; Posof ilçesinde Yaban Hayatı Koruma Sahası oluşturulmuştur. Ardahan'a özgü; Kızıl Tilki, Huş Tavuğu, Karaca ve Dağ Keçisi koruma altındadır (www.kulturportali.gov.tr).

Şeytan Kalesi; Ardahan'da Urartular döneminde yapıldığı tahmin edilen Şeytan Kalesi, sarp kayalıkların üzerinde konumlandırılmıştır. Gizli giriş kapısı bulunan kale, sunduğu eşsiz manzarasıyla turistlerin ve diğer ziyaretçilerin ilgi odaklarından birisidir (www.cnnturk.com).

Övündü ve Ortakent (Büyük Nakala) Mağaraları; Bu mağaraların Yontma Taş Çağı izlerini taşıdığı belirtilmektedir (https://ardahan.ktb.gov.tr).

Damal Bebekleri; Damal ve yöresindeki kadınların tarihte kullandıkları kıyafetleri, yöresel motiflerle kumaş ve boncuk işleyerek giydirdikleri minyatür bebeklere Damal Bebeği denilmektedir. Bir Orta Asya kültürü olan Damal giysileri; 1980 li yıllara kadar yöredeki, kız, gelin ve evli bayanlar tarafından giyilmekteydi. Türk Patent Enstitüsü’nün 48 nolu kararı ile tescil edilmiştir (http://damal.meb.gov.tr).

Ardahan - Kars Kazı; Türkiye'de kaz yetiştiriciliğinin en önemli merkezi Kars ve Ardahan'dır. Yörenin en önemli gastronomik lezzetlerinden biri olan kaz eti özellikle kışın "öğün değil, özel yemek" olarak sofraları süslemektedir (www.yenisafak.com). Ardahan'ın yenmesi gereken en güzel gastronomik ürünlerden birisi "Kaz" etidir (www.ardahan.gov.tr).

Ardahan Çiçek Balı; Bölgenin florası bal üretimine eşsiz lezzet ve kalite sunmaktadır. Bu nedenle, Ardahan Çiçek balı Türk Patent Enstitüsü tarafından 'coğrafi işaret belgesi' ile tescillendirilmiştir (www.serka.gov.tr). Ayrıca Kafkas Arısı; "Hayvan Irklarının Tesciline İlişkin Yönetmelik" kapsamında tescil edilmiştir ( www.tarimorman.gov.tr).

Ardahan Kars Kaşar Peyniri; Coğrafi İşaretin Adı "Kars Kaşarı" olan kaşar peyniri, Kars merkez ve Ardahan merkez ve diğer ilçelere bağlı köy, mezra ve yaylarda üretilebilmektedir (www.turkpatent.gov.tr).

Posof İçi Dışı Kırmızı Elması; Posof elmasının içi ve dışı kırmızıdır. Posof'un kendine özgü iklimi elmanın rengini ve tadını etkilemektedir. Yöre halkına göre Posof elması şeker hastalığına iyi gelmektedir (www.posof.gov.tr).

Özetle, Ardahan kentinin turistik, gastronomik, tarihsel ve ekonomik ürünleri şunlardır: Atatürk silueti, kiliseler, kuş gözlem alanları, kaleler, kayak merkezi, Çıldır gölü, Kura nehri, endemik bitki örtüsü, yaban hayat, Şeytan kalesi, mağaralar, Damal bebekleri Ardahan kazı, Ardahan çiçek balı, kaşar peyniri ve Posof elmasıdır.

\section{ARAŞTIRMANIN YÖNTEMI}

Ardahan kenti; dağ ve doğa yürüyüşleri, sportif olta balıkçllğı̆, yayla turizmi, kuş gözetleme, mağara turizmi, atlı doğa yürüyüşü, kış turizmi, atlı kar kızakları, yaban hayat, gastronomisi (kaşar peyniri, kazı ve çiçek balı), festivalleri ile iç ve dış turizm destinasyonu olarak gelişme 
göstermektedir. Bu nedenle Ardahan kentinde yer alan kurum ve kuruluşların kentin sahip olduğu yerel ve doğal değerlere ait simge, sembol ile mitolojik imgeleri logo ve amblemlerde yansıtma derecesi araştırılacaktır. Böylece konuya dikkat çekilerek Ardahan kenti üzerine farkındalık oluşturulmaya çalışılmıştır.

Araştırmanın evrenini Ardahan kentinde yer alan kamu kurumlarının ve yerel yönetimlerin logoları ve amblemleri oluşturmaktadır. Kuruluşlar şunlardır: Ardahan Valiliğii, Ardahan Belediyesi, Ardahan Sanayi ve Ticaret Odası, Ardahan Üniversitesi, Çıldır Belediyesi, Hanak Belediyesi, Posof Belediyesi, Damal Belediyesi, Göle Belediyesi. Ardahan İl Kültür ve Turizm Müdürlüğünün Logo ve Amblemi internet sayfasında Kültür ve Turizm Bakanlığının Logo ve Amblemi kullanıldığından değerlendirmeye alınmamıştır. Söz konusu kurumların internet sayfalarına 24.05.2020 tarihinde erişim sağlanmıştır.

Çalışmada, Ardahan Sanayi ve Ticaret Odası ve Ardahan Üniversitesinin logo ve ambleminin anlamına internet adresi üzerinden ulaşılmıştır.

Ardahan Valiliği, Çıldır, Hanak, Posof, Damal ve Göle Belediyesinin logolarının anlamları ile ilgili bilgiler için Cumhurbaşkanlığı İletişim Merkezi (CIMER) üzerinden bilgi istenmiştir. Ardahan Belediyesinin logo anlamının cevabı CIMER üzerinden alınmıştır. Diğer kurumların cevapları ise e-posta ile araştırmacıya gönderilmiştir.

Gelen cevaplar doğrultusunda logo ve amblemlerin içerik analizi yapılmıştır.

İçerik analizinde, benzer verileri belirli kavramlar ve temalar çerçevesinde bir araya getirmek ve bunları belli bir biçimde düzenleyerek yorumlamaktır. İçerik analizinden yararlanılarak yapılan incelemede; logolarda kullanılan simgelerin yerel tarih, kültürel öz değerler, doğal çevreyi yansıtma başarısı göz önünde bulundurularak değerlendirilmeye çalışılmıştır (Yenipınar ve Yildırım, 2016; 33).

\section{Araştırmanın Kısıtları}

Araştırmaya konaklama işletmeleri, seyahat işletmeleri, köyler, diğer kamu ve tüzel işletmeler ve Sivil Toplum Kuruluşlarının logo ve amblemleri dahil edilmemiştir.

\section{BULGULAR}

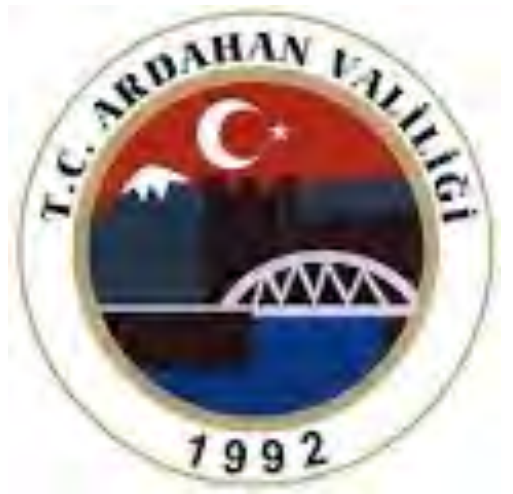

Şekil 2: Ardahan Valiliği Logosu

Şekil 2'de Ardahan Valiliğinin logosu yer almaktadır. Ardahan 27 Mayıs 1992 yılında il statüsü kazanmıştır. Amblemde yer alan köprü, 110 yıllık tarihi Rus demir köprüsüdür. Mavi renk ise, Gürcistan, Azerbaycan ve oradan da Hazar denizine dökülen Kura Nehrini temsil etmektedir. Tarihi köprünün arkasında ise 16. yüzyılda Kanuni Sultan Süleyman emriyle inşa edilen Ardahan 
Kalesi, bulunmaktadır. Ayrıca, sol üstte yer alan beyazlık ise yılın 9 ayı zirvesinde kar eksik olmayan dağları temsil etmektedir. Bununla birlikte ay-yıldızlı bayrağımız ile logo ve amblem bütünleşmiştir.

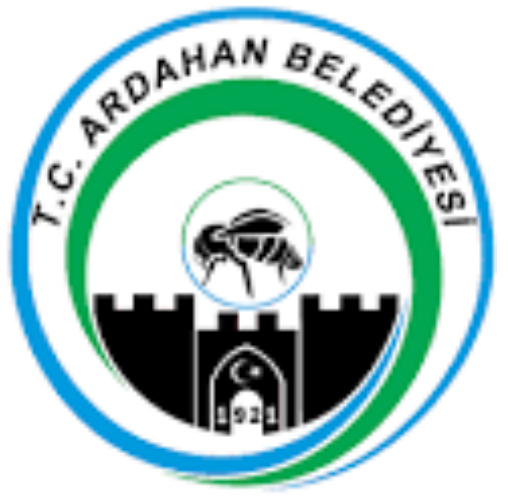

Şekil 3: Ardahan Belediyesi Logosu

Şekil 3'te yer alan Ardahan Belediyesinin logosudur. Kalesiyle, Kafkas ırkı arısıyla doğası ve Kür (Kura) nehri ile tanınan Ardahan'ın logosunda bu unsurlar ön plana çıkıyor. Logodaki mavi sarmal, Kür (Kura) ırmağının 12 ay sürekli akan dere, çay, ırmak ve sulak alanları temsil eder. Kafkas Ana Arı, sakin, fedakâr, üretken bir arı ırkı olan Kafkas bal arısının gen merkezi Ardahan'dır. Aynı zamanda kısa yaz sezonunda halkın yüksek üretkenliğini, tedbirli olmasını, minimum imkânlarla maksimum faydayı sağlamasını temsil eder. Kale, Ardahan Kalesini Ardahan'ın serhat şehir olduğunu, dik durmayı, sağlam durmayı, vatanseverliği temsil eder. Ayrıca tarihi bir şehir olduğunu temsil eder. 1921 Tarihi, Ardahan Belediyesinin kuruluş tarihini temsil etmektedir. Renk dilinde yeşil; yeniden doğuşu, yenilenmeyi, sürekliliği, huzuru ve güveni ifade etmektedir. Ana renk olarak seçilen yeşil, kentin doğasını, çayırlarını, kırlarını temsil etmekte ve belediyenin çevreye karşı olan hassasiyetini vurgulamaktadır.

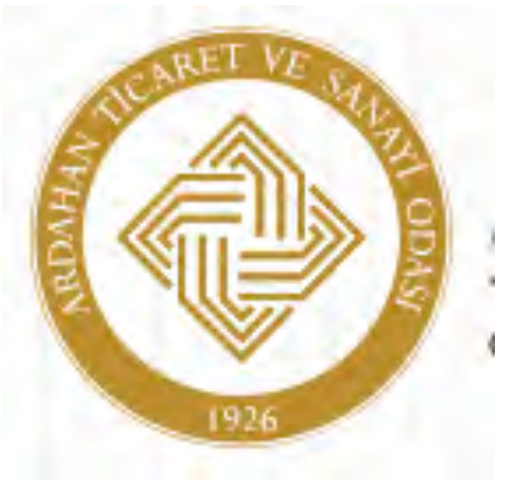

Şekil 4: Ardahan Ticaret Odası Logosu

Şekil 4'te Ardahan Ticaret Odasının logusu bulunmaktadır. Logo iç içe geçmiş şekilde kurgulanarak stilize edilmiş 4 adet A bulunmaktadır. Bu " $\mathrm{A}$ " harfi Ardahan ilinin baş harfi olmakla beraber Ardahan ilinin 4 temel ticari dinamiğini temsil etmektedir. Bunlar; turizm, hayvancılık, sınır ticareti ve doğal tabiat yaşamıdır. Logoda kullanılan altın rengi ise Ardahan ilinin sahip olduğu zenginliği ifade etmektedir. 


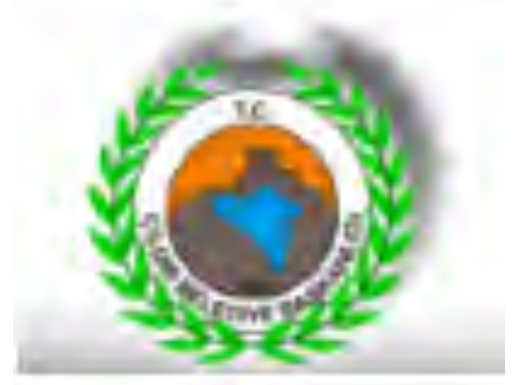

Şekil 5: Çıldır Belediyesi Logosu

Şekil 5'de Çıldır Belediyesinin logosu yer almaktadır. Çıldır Belediye Başkanlığı logosunda mavi, kahverengi ve yeşil renkleri kullanılmıştır. Mavi renk Çıldır Gölünü, kahverengi renk Çıldır'da bulunan Şeytan Kalesini yeşil rengin bir tarafı Zeytin Dalını yani barışı diğer yeşil renk ise buğdayı yani bereketi simgelemektedir.

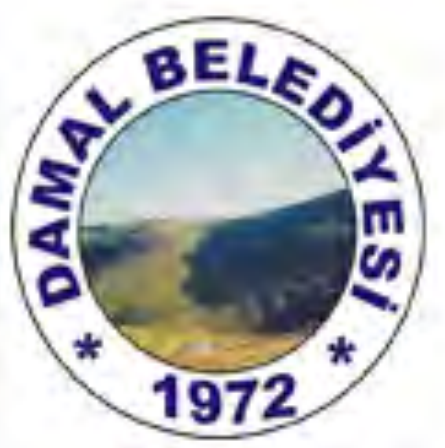

Şekil 6: Damal Belediyesi Logosu

Şekil 6'da Damal Belediyesinin logosuna yer verilmiştir. Damal Belediyesinin logosunda Türkiye Cumhuriyeti'nin Kurucusu Ulu Önder Mustafa Kemal Atatürk'ün silueti yer almaktadır. Ardahan'ın Damal ilçesinde doğal mucize olarak nitelendirilen Ulu Önder Mustafa Kemal Atatürk silueti, her yıl 15 Haziran - 15 Temmuz tarihleri arasında ortaya çıkıyor. (www.haberler.com).

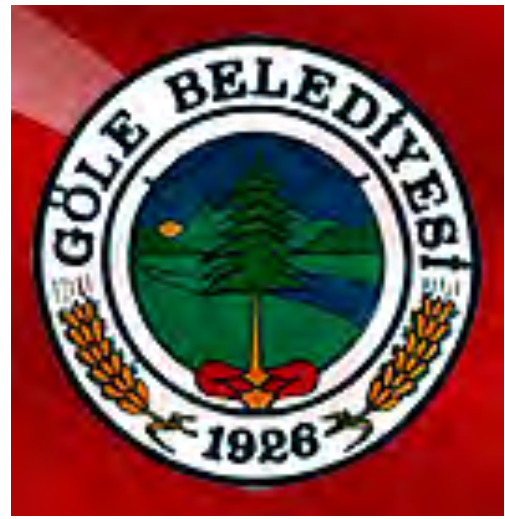

Şekil 7: Göle Belediyesi Logosu

Şekil 7' de Göle Belediyesinin logosuna yer verilmiştir. Göle Belediyesinin bir kısmı orman ve çam ağaçları ile diğer kısmı ise çayır ve mera alanları ile kaplıdır. Her tarafı yeşil olduğu için yeşil Göle adını alıp temsili olarak belediye logosunda kullanılmıştır. 


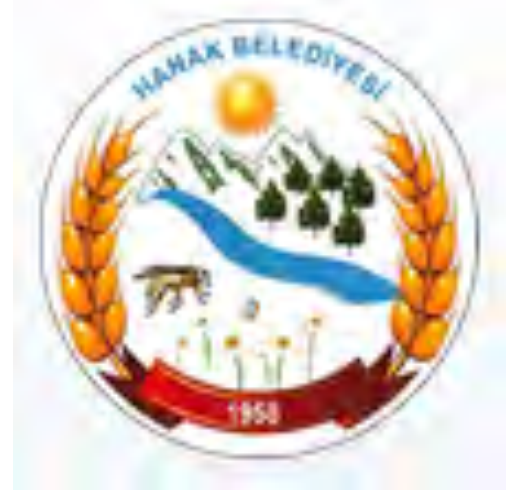

Şekil 8: Hanak Belediyesi Logosu

Şekil 8'de Hanak Belediyesinin logosu yer almaktadır. Hanak Belediyesinin logosundaki işaretler: Arı, bölgede arıcılık çok yoğun yapılmakta ve çok fazla ballı endemik çiçek çeşidi bulunmaktadır. Ayrıca dünyadaki en iyi arı ırklarından 4 ünden biri olan Kafkas Arı ırkını temsil eder. Çiçek, ilçede 2000'e yakın çiçek çeşidi ve çok sayıda endemik çiçek bulunmaktadır. Çam Ağacı, ilçenin rakımı yüksek olması nedeniyle rahatlıkla yetişebilen ağaç türüdür. Başak, ilçede yetiştirilmekte olan arpa ve buğdayı yani tarımı temsil etmektedir.

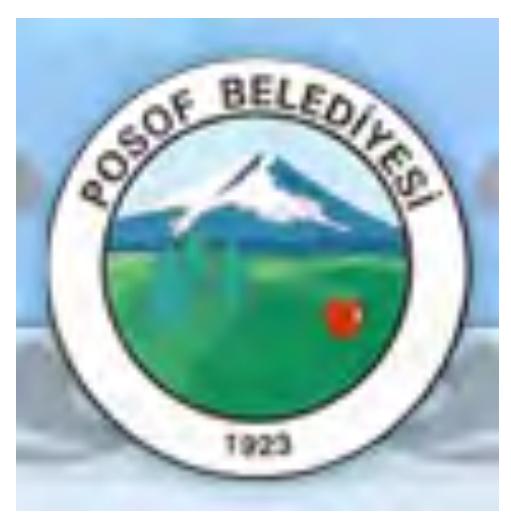

Şekil 9: Posof Belediyesi Logosu

Şekil 9'da Posof Belediyesinin logosu yer almaktadır. Posof Belediyesinin logo açılımında kullanılan renkler ilçenin ilkbahar ve sonbahar döneminde özellikle yeşil ve sarının her tonunun doğada hakim olduğu renk cümbüşünden esinlenmiştir. İlçede endemik birçok bitkiye ve meyveye ev sahipliği yapmakla birlikte coğrafi işaretinin Belediyeye ait olduğu içi ve dışı kırmızı elmanın sadece Posof'ta yetişmekte olduğundan logoda yer almaktadır.

Şekil 10'da Ardahan Üniversitesinin logosuna yer verilmiştir. Ardahan Üniversitesi'nin logosu, Kafkasya ve Orta Asya halklarınca sıkça kullanılan koçbaşı figüründen kompoze edilen, ortasında insan figürü bulunan bir kar tanesidir. Kar tanesi, başkasına benzememeyi simgelemektedir. İnsan figürü ve yanındaki nokta ise, her şeyin de bir noktadan başladığını simgelemektedir. 


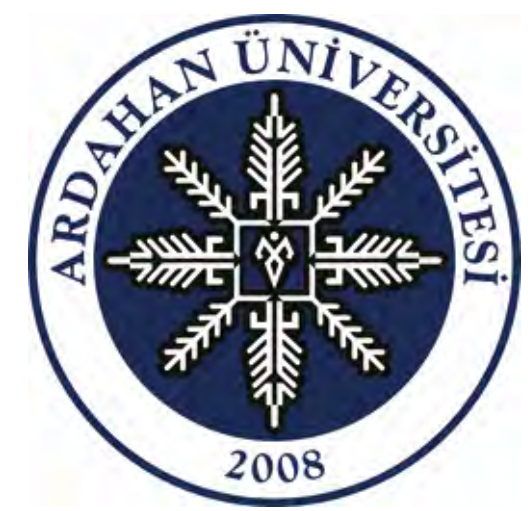

Şekil 10: Ardahan Üniversitesi Logosu

Araştırmada, 9 adet kurum ve kuruluşa ait logo ve amblem tarihi, kültürel, mitolojik ve turistik ve gastronomik değerleri yansıtıp yansıtmadıkları açısından incelenmiştir.

Tablo 1. Logosu İncelenen Kurumlara Ait İçerik Analizi

\begin{tabular}{|c|c|c|c|c|c|c|c|c|c|}
\hline $\begin{array}{l}\text { Ardahan Kentinin } \\
\text { Turistik, } \\
\text { Gastronomik ve } \\
\text { Ekonomik Öz } \\
\text { Değerler }\end{array}$ & 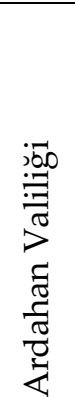 & 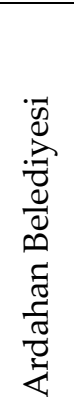 & 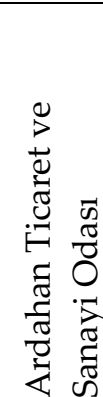 & 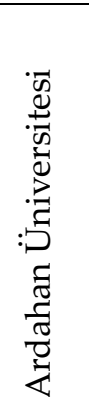 & 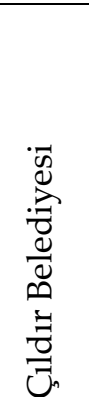 & 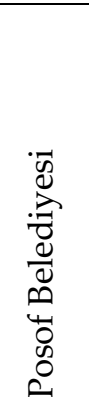 & 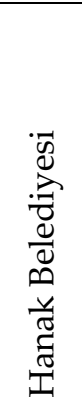 & 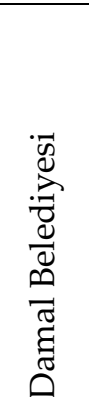 & 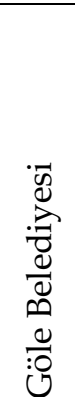 \\
\hline Atatürk Silueti & Yok & Yok & Yok & Yok & Yok & Yok & Yok & Var & Yok \\
\hline Kiliseler & Yok & Yok & Yok & Yok & Yok & Yok & Yok & Yok & Yok \\
\hline Kuş Gözlem & Yok & Yok & Yok & Yok & Yok & Yok & Yok & Yok & Yok \\
\hline Kaleler & Var & Var & Yok & Var & Var & Var & Var & Yok & Yok \\
\hline Kayak Merkezi & Yok & Yok & Yok & Yok & Yok & Yok & Yok & Yok & Yok \\
\hline Çıldır Gölü & Yok & Yok & Yok & Yok & Var & Yok & Yok & Yok & Yok \\
\hline Kura Nehri & Var & Yok & Yok & Yok & Yok & Yok & Yok & Yok & Yok \\
\hline $\begin{array}{l}\text { Endemik Bitki } \\
\text { Örtüsü }\end{array}$ & Yok & Yok & Yok & Yok & Yok & Yok & Var & Yok & Yok \\
\hline Yaban Hayat & Yok & Yok & Yok & Yok & Yok & Yok & Yok & Yok & Yok \\
\hline Şeytan Kalesi & Yok & Yok & Yok & Yok & Var & Yok & Yok & Yok & Yok \\
\hline Mağaralar & Yok & Yok & Yok & Yok & Yok & Yok & Yok & Yok & Yok \\
\hline Damal Bebekleri & Yok & Yok & Yok & Yok & Yok & Yok & Yok & Yok & Yok \\
\hline Ardahan Kazı & Yok & Yok & Yok & Yok & Yok & Yok & Yok & Yok & Yok \\
\hline Ardahan Çiçek Balı & Yok & Yok & Yok & Yok & Yok & Yok & Var & Yok & Yok \\
\hline Kaşar Peyniri & Yok & Yok & Yok & Yok & Yok & Yok & Yok & Yok & Yok \\
\hline Posof Elması & Yok & Yok & Yok & Yok & Yok & Var & Yok & Yok & Yok \\
\hline
\end{tabular}

Tablo 1'de Ardahan Kentinin Turistik, Gastronomik ve Ekonomik öz değerlere logolarda yer verilip verilmediği ayrıntılı olarak analiz edilmiştir.

Ardahan Valiliğinin logosunda Ardahan Kalesi yer almaktadır. Ayrıca dağlarında yılın 270 günü kar olduğunu gösteren kar şapkası yer almaktadır. Ay yıldızlı bayrağımız ise en üstte amblemi kucaklamaktadır. Ardahan Valiliğinin logosunun birden çok nesne kullanılmasından dolayı sade olmamakla birlikte akılda kalıcı olmadığı düşünülmektedir. Ardahan Valiliği yazısı okunaklıdır. 
Amblem kırmızı renk ile dikkat çekiyor Kura nehrinin maviliği ile dinlendirici bir renk tercih edildiği görülmektedir. Ardahan Valiliğinin ambleminin özgün olmadığı söylenebilir.

Ardahan Belediyesi logosunda mavi ve yeşil renk ile doğa vurgusu yapılmıştır. Ardahan kalesi ile tarihi bir görsel ve bal arısı ile de Ardahan'ın gastronomik ürününe vurgu yapılmıştır.

Ardahan Sanayi ve Ticaret Odası tanımlamasına göre, logo iç içe geçmiş şekilde kurgulanarak stilize edilmiş 4 adet " $A$ " vardır. "A " harfi Ardahan ilinin baş harfi olmakla beraber Ardahan ilinin 4 temel ticari dinamiğini temsil etmektedir. Bunlar, hayvancılık, turizm, sınır ticareti, doğal tabiat yaşamıdır. Bu logo ve amblem ile "A" harfi çok net olarak ortaya çıkmamakla birlikte, kullanılan renk ile üç önemli gastronomik ürüne (altın sarısı renginde derisi olan kaz, bal ve kaşar peyniri) atıfta bulunulduğu düşünülebilir. Ardahan'da hangi ticari faaliyet ön planda ise bunun kullanılması uygun olacağı düşünülmektedir. Ardahan ekonomisinde önemli yere sahip olan hayvancılık nedeniyle "Boğa" kullanılması bilinirliği artırabilirdi.

Ardahan Üniversitesinin logo ve ambleminde, Ardahan'ın turistik, gastronomik ve ekonomik çă̆rışımları yapan herhangi bir nesne kullanılmamıştır. Kafkas bölgesinde halı ve diğer el sanatlarında kullanılan koç başının tasvir edildiği görülmektedir.

Çıldır Belediyesinin logo ve ambleminde Çıldır gölü yer almakla birlikte kış turizmde önemli bir destinasyon olan ve ziyaretçilerin önem verdikleri atlı kar kızaklarına yer verilmediği görülmektedir. Şeytan Kalesi önemli bir tarihi eser olmakla birlikte Çıldır gölünün maviliği baskın gelmektedir. Logo ve amblemde yer alan mavilik her ne kadar Çıldır gölünü temsil etse de aklılarda kalan net bir mesaj vermemektedir.

Posof belediyesinin logo ve ambleminde yeşil renk ve doğa ön plana çıkmıştır. Arka planda yer alan karlı dağlar Posof belediyesinin coğrafyası ile ilgili değildir. Posof Belediyesi tarafından tescil edilen Posof elması logo ve amblemde yer almakla birlikte çok küçük kalmıştır. Sadece bir nesnenin ön plana çıkarılması bilinirliği ve akılda kalıcılığı artıracağı söylenebilir. Bu nesne içi ve dışı kırmızı olan Posof elması olmasının bilinirliği artıracağı düşünülmektedir.

Hanak Belediyesin logo ve ambleminde Ardahan çiçek balına çağrışım yapan arı ve endemik bitki örtüsüne göndermede bulunan çiçeklerin yer aldığı görülmektedir. Ardahan ekonomisinde önemli bir yeri olan arpa ve buğday üretimi ile ilgili olarak başak kullanıldığı görülmektedir.

Damal Belediyesinin logosunda Türkiye Cumhuriyeti'nin Kurucusu Ulu Önder Mustafa Kemal Atatürk'ün silueti yer almaktadır. Destinasyon süreci sadece 15 Haziran- 15 Temmuz tarihleri arasındadır. Damal Belediyesi, Damal Bebekleri ile Atatürk silueti arasında Atatürk siluetini tercih ettiği görülmektedir. Yapılan "Atatürk'ün İzinde ve Gölgesinde Damal Şenlikleri" etkinlikler ile Damalın tanıtımına katkı sağlayacağı düşünülmektedir. 15 Haziran - 15 Temmuz bölgenin en yeşil olduğu dönemdir. Bu nedenle ziyaretçilere eşsiz bir deneyim sunduğu söylenebilir.

Göle Belediyesinin coğrafyası bir kısmı orman ve çam ağaçları ile diğer kısmı ise çayır ve mera alanları ile kaplıdır. Bu nedenle, her tarafı yeşil olduğu için yeşil Göle adını alıp temsili olarak belediye logosunda yeşil bitki örtüsü ve çam ağacı kullanıldığı görülmektedir. Göle hayvancılık için elverişli bir arazi yapısına sahiptir. Bu nedenle logoda hayvancllık ile ilgili nesneye yer verilmesinin faydalı olacağı düşünülmektedir.

\section{TARTIŞMA SONUÇ ve ÖNERILER}

Kent logoları, kurumsal bir kimlik ile destinasyon markalamasının mesajını, etkinliklerini, turistik ve gastronomik öz değerlerini tüketiciler ile buluşturan görsel göstergelerdir. Bu 
özellikleriyle oldukça net, sade nesneler ve bilgiyle kitlesine hitap etmeleri, kentin destinasyon markalamasında rekabetçi ve akılda kalıcı kimliğini desteklemelidir. Bu açıdan değerlendirildiğinde; Ardahan kentine ait 9 adet destinasyon yönetim organizasyonuna ait logoların içerik analizi yapılmıştır. Araştırmanın önemli bulgularından birincisi; Ardahan kentinin destinasyon markalaması açısından tarihi ve kültürel değerlerini ön plana çıkarmada istekli görülmektedir.

Destinasyon markalamasında gastronoimik ürünler önemli birer markalama araçlarıdır. Sadece Ardahan balına çağrışım yapan arı kullanılmıştır. Kaz ve Kaşar peyniri ve hayvancılık ile ilgili nesneler kullanılmadığı görülmüştür. Belediye ve valiliğin logolarında ortak bir nesne kullanılmamıştır.

Kiliseler, kuş gözlem, kayak merkezi, mağaralar, Damal Bebeği, Kars-Ardahan Kazı ve KarsArdahan Kaşarı logolarda nesne olarak kullanılmadığı görülmüştür.

Bu çalışmada, Belediyeler, Valilik, Ticaret ve Sanayi Odası logolarında genel olarak kentin en önemli turistik, tarihi ve gastronomik yapıtının kullanıldığı görülmüştür. Ancak her logoda birden fazla nesne kullanıldığından akılda kalıcılığı azalttığı gözlenmiştir.

Ardahan kentini tanıtma ve temsili açısından logoların ihtiyacı tam olarak karşılamadığı gibi kurumsal kimlik ve destinasyon markalaması açısından sade ve akılda kalıcılığı sağlamadığı söylenebilir.

Önemli destinasyon merkezleri olmak isteyen kentler güçlü marka kimliğine sahip olmalıdır. Kentler için marka kimliği oluşturmada logo ve amblemlerin önemli olduğu söylenebilir. Turizm gelirlerinden pay almak isteyen kentlerin turistik planlama ve pazarlama faaliyetlerinde ve markalaşmada logo ve amblem konusunu dikkate almaları gerektiği söylenebilir.

Sonuç olarak, Ardahan Valiliği, Ardahan Ticaret ve Sanayi Odası, Ardahan Üniversitesi, Ardahan, Çıldır, Posof, Hanak, Damal ve Göle Belediyesinin Ardahan kentinin tanıtımı için logo ve amblem hazırlamada birbiri ile koordineli hareket etmeleri önerilebilir. Böylece logo ve amblemlerde ortak ve birden fazla nesnenin kullanımının önüne geçilmiş olur. Ardahan kentine ait turistik, gastronomik ve ekonomik ürünlerin logolarda kullanılması ile ilgili şu önerilerde bulunulabilir. Ardahan Valiliği için; Yanlızçam kayak merkezine logoda öncelik verilebilir. Çünkü Yalnızçam kayak merkezi kar kalitesi nedeniyle kış turizmi açısından önemli bir tesistir. Ardahan Belediyesi için; arı, bal, kaz veya kaşar peynirini simgeleyen sembollerden biri kullanılabilir. Ardahan Ticaret ve Sanayi Odası için; arı, bal, kaşar peyniri, kaz veya büyükbaş hayvanı (boğa) simgeleyen nesnelerden biri kullanılabilir. Ardahan Üniversitesi için; mevcut logosunda koç başı daha belirgin hale getirilebilir. Çıldır Belediyesi için; atlı kar kızakları ve şeytan kalesi logoda nesne olarak ön plana çıkarılabilir. Böylece, kış turizmi için niş pazar oluşturabilir. Posof Belediyesi için; Posof elmasının arz talep dengesi gözetilerek gastronomik ürün olarak kullanılabilir. Hanak Belediyesi, endemik bitki örtüsü ile niş turistik pazar oluşturabilir. Damal Belediyesi; Atatürk Silueti doğaüstü bir olay olarak logoda kullanıldığ1 görülmektedir. Göle Belediyesi; büyükbaş hayvan (boğa), arı, bal veya kaşar peyniri simgelerinden biri kullanılabilir.

\section{KAYNAKÇA}

Acar, Y. (2018). Turistlerin Tercih Edilen Destinasyona Yönelik Bilgi Düzeyleri: Türkiye'deki Sakin Şehirleri Ziyaret Eden Yerli Turistler Üzerine Bir Araştırma. Aksaray Üniversitesi Sosyal Bilimler Enstitüsü Dergisi, 2 (1), 45-56. 
Aliağaoğlu, A. ve Uğur, A. (2018). Logolarda Erzurum Kent Kimliği: Yorumlayıcı Anlamaya Yönelik Bir Çalışma. Atatürk Üniversitesi Sosyal Bilimler Enstitüsü Dergisi, 22 (4), 2357-2379.

Ardahan Haber. (2012). https://www.ardahanhaber.com.tr/ardahan-belediyesi-logosunuyeniledi/5405/ [Erişim Tarihi: 24.05.2020].

Ardahan Ticaret ve Sanayi Odası (2015). http://www.ardahantso.org.tr [Erişim Tarihi: 24.05.2020].

Aslan, Z., Güneren, E. ve Çoban, G. (2014). Destinasyon Markalaşma Sürecinde Yöresel Mutfağın Rolü: Nevşehir Örneği. Journal of Tourism and Gastronomy Studies 2 (4), 3-13.

Aycı, A. (2020). İşletmelerin Logolarını Değiştirme Nedenleri, Yöntemleri ve Sonuçları: Vakıfbank Örneği. Uluslararası İktisadi ve İdari İncelemeler Dergisi, 2020 (26), 19-34.

Bayraktaroğlu, A. ve Çalış, E. (2011). Amblem ve Logo Tasarımlarında Yalınlaştırmalar. Süleyman Demirel Üniversitesi Güzel Sanatlar Fakültesi Hakemli Dergisi, Art-e Sanat Dergisi, 3 (6), 1-22.

Belge, R. (2018). Denizli Kent Kimliğini Oluşturan Coğrafi Öğeler. Ege Coğrafya Dergisi, 27 (2), $167-181$

Bilirdönmez, T. ve Şahin, C. (2019). Doğu Karadeniz Bölgesi Şehirlerinin Belediye Logolarındaki Tanıtıcı Sembollerin Analizi. Maarif Mektepleri Uluslararası Sosyal ve Beşeri Bilimler Dergisi, 2 (2), $38-47$.

Birol Özerk, G. ve Akgün Yüksekli, B. (2010). Küresel Kent, Kentsel Markalaşma ve Yok-Mekân İlişkileri. İdealkent, 2 (3), 82-93.

Ceylan, İ. (2016). Amblem ve Logo Tasarımlarında Renklerin Dili. Art-e Sanat Dergisi, 8 (16), 314330.

CNN Türk. (2019). https://www.cnnturk.com/yasam/ardahanda-bir-orta-cag-kalesi-seytankalesi?page $=1$ [Erişim Tarihi: 26.06.2020].

Çakır, E. (2013). Akademik Dünyanın Kentsel İmgelerinden Mitolojik Simgelerine Üniversite Logoları. Millî Folklor, 25 (97), 53-69.

Çalış Zeğerek, E. (2019). Tarihsel Süreçte Rebus ve Kullanım Alanları. Yedi: Sanat, Tasarım ve Bilim Dergisi, 2019 (22), 31-40.

Çiçek, R. ve Ilgaz, A. (2015). Destinasyonların Pazarlanmasında İmaj ve Markanın Rolü: Nevşehir Örneği. Akademik Bakış Uluslararası Hakemli Sosyal Bilimler Dergisi, (48), 171-183.

Demir, H. (2018). Adana Mersin ve Antalya'nın Kimlik Göstergeleri Olarak Kent Logolarını Çözümlemek, İdil Sanat ve Dil Dergisi, 7 (52), 1573-1584.

Demir, Ş. ve Tür, E. (2019). Otel logosu ne söyler? Tüketiciler ne algılar? Journal of Tourism Theory and Research, 5 (1), 51-64.

Deneçli, S. (2015). The Effect Of Consumers' Attıtudes Towards Logos Or Emblems On Brand Preference. Marmara Üniversitesi Öneri Dergisi, 11 (44), 319-335.

Esmeray, M. (2018). Amblem ile Sembolik Tüketim Arasındaki İlişkinin İncelenmesi: Starbucks Örneği Çukurova Üniversitesi II. Uluslararası Sanat Araştırmaları Sempozyumu 11-14 Nisan 2018.

Gemci, R., Gülşen, G. ve Kabasakal, M. (2009). Markalar ve Markalaşma Şartları, Uludă̆ Üniversitesi Mühendislik-Mimarlık Fakültesi Dergisi, 14 (1), 105-114.

Görgülü, Y. (2019). Kentlerin Markalaşması Sürecinde Logoların Kimlik İnşası: Antalya Örneği Göstergebilimsel Bir Çözümleme. Elektronik Cumhuriyet İletişim Dergisi, 1 (3), 65-83. 
Haberler.com. https://www.haberler.com/ataturk-siluetinin-yansidigi-mahallede-kafa-12672492haberi/[Erişim Tarihi: 10.06.2020].

Kahraman, M. E. (2011). Marka Oluşturma Aşamasında Amblemin Yeri ve Önemi. Sanat Dergisi, (20), 107-115.

Keş, Y. ve Yıldız, M. (2018). Televizyon Dizilerinin Markalaşma Sürecinde Logo. Yıldız Journal of Art and Design, 5 (2), 67-88.

Kılıç, B. ve Uslu, T. (2019). Porter'in Rekabet Modelinin İstanbul'daki Zincir Otel İşletmelerinde İncelenmesi. Uluslararası Global Turizm Araştırmaları Dergisi, 3 (2), 83-98.

Kılıç, B. ve Uslu, T. (2019). Stratejik Yönetim Açısından İstanbul'daki Yerli ve Yabancı Marka Zincir Otellerin Rekabeti Sürdürmede Öncelik Verdikleri Temel Yetenekler. Akademik Sosyal Araştırmalar Dergisi, 7 (97), 212-230.

Köroğlu, A. ve Yağcl, P. (2018). Türkiye'deki Şehirleri Simgeleyen Logoların Doğal ve Kültürel Miras Unsurları Açısından Çözümlenmesi. Turizm Akademik Dergisi, 5 (1), 63-85.

Köse, G. (2020). Reklam Ajanslarının Sektörel Dergilerdeki İlanlarının Kurumsal Tasarım Unsurları Bağlamında İncelenmesi. Gaziantep Üniversitesi Sosyal Bilimler Dergisi, 19 (1), 190-203.

Köşker, H., Albuz, N. ve Ercan, F. (2019). Türkiye'de Turistik Talebin En Fazla Olduğu 10 Kentin Marka Kimlikleri Üzerine Bir Değerlendirme. Gaziantep Üniversitesi Sosyal Bilimler Dergisi, 18 (1), 348-365.

Millî Eğitim Bakanlığı. (2012). Grafik ve fotoğraf. Amblem ve Logo, 213GIM025, Ankara http://megep.meb.gov.tr/mte_program_modul/moduller_pdf/Amblem\%20Ve\%20Logo.pdf [Erişim Tarihi: 05.07.2020].

Milli Eğitim Bakanlığı. (2012). http://megep.meb.gov.tr/mte_program_modul/moduller_pdf/Amblem\%20Ve\%20Logo.pdf [Erişim Tarihi: 05.07.2020].

Morçin, S. E. ve İşler, D. B. (2017). Destinasyon Sloganlarında Kullanılan Temaların Analizi. Süleyman Demirel Üniversitesi İktisadi ve İdari Bilimler Fakültesi Dergisi, 22 (4), 1081-1090.

Nas, A. (2017). Branding and National Identity: The Analysis of "Turkey: Discover The Potential" Campaign. Bilig, (83), 201-224.

Özderin, S. (2019). Kurumsal Kimlik Kavramı Açısından Logo/Amblem Tasarımlarında Düşünsel Yaklaşımla. Akademik Sosyal Araştırmalar Dergisi, 6 (37), 191-206.

Serçek, S. ve Hassan, A. (2016). Turizmde Destinasyon Markalaşması ve Diyarbakır Örneği. Seyahat ve Otel İsletmeciliği Dergisi, 13 (1), 6-27.

Serhat Kalkınma Ajansı. (2012). https://www.serka.gov.tr/assets/upload/dosyalar/ardahanyuruyus-parkurlari.pdf [Erişim Tarihi: 26.06.2020].

Serhat Kalkınma Ajansı. (2018). https://www.serka.gov.tr/cografi-isaretli-urunlerimiz/ardahancografi-isaretli-urunler/ardahan-bali [Erişim Tarihi: 14.06.2020].

T.C. Ardahan Belediye Başkanlığı. (2020). https://www.ardahan.bel.tr/ [Erişim Tarihi: 24.05.2020

T.C. Ardahan İl Kültür ve Turizm Müdürlüğü. (2020). https://ardahan.ktb.gov.tr/TR55789/magara-turizmi.html [Erişim Tarihi: 26.06.2020].

T.C. Ardahan Üniversitesi. https://www.ardahan.edu.tr/detay-menu.aspx?id=82 [Erişim Tarihi: 24.05.2020]. 
T.C. Ardahan $\quad$ Valiliği. http://ardahan.gov.tr/ardahan-in-cografikonumu\#: :text=Anadolu'nun\%20kuzeydo\%C4\%9Fusunda\%20yer\%20alan,da\%20Artvin\%20ill eri\%20ile\%20\%C3\%A7evrilidir. [Erişim Tarihi: 04.07.2020].

T.C. Ardahan Valiliğii. http://www.ardahan.gov.tr [Erişim Tarihi: 24.05.2020].

T.C. Ardahan Valiliği. http://www.ardahan.gov.tr/ardahan-kalesi [Erişim Tarihi: 02.07.2020].

T.C. Ardahan Valiliği. http://www.ardahan.gov.tr/goller-ve-nehirler. [Erişim Tarihi: 24.06.2020].

T.C. Ardahan Valiliği. http://www.ardahan.gov.tr/kaz-yemegi [Erişim Tarihi: 12.06.2020].

T.C. Ardahan Valiliği. http://www.ardahan.gov.tr/yalnz28122018 [Erişim Tarihi: 24.06.2020].

T.C. Çıldır Belediye Başkanlığı. http://www.cildir.bel.tr/ [Erişim Tarihi: 24.05.2020].

T.C. Çıldır Kaymakamlığı. (2020). http://cildir.gov.tr/cildir-golu [Erişim Tarihi: 24.06.2020].

T.C. Damal Belediye Başkanlığı. (2020). http://damal.bel.tr/ [Erişim Tarihi: 24.05.2020].

T.C. Göle Belediye Başkanlığı. https://www.gole.bel.tr/[Erişim Tarihi: 24.05.2020].

T.C. Hanak Belediye Başkanlığı. http://www.hanak.bel.tr/[Erişim Tarihi: 24.05.2020].

T.C. Milli Eğitim Bakanlığı (2016). http://damal.meb.gov.tr/www/damal-bebekleri/icerik/14 [Erişim Tarihi: 12.06.2020].

T.C. Posof Belediye Başkanlığı. http://www.posof.bel.tr/ [Erişim Tarihi: 24.05.2020]

T.C. Posof Kaymakamlığı. http://www.posof.gov.tr/posof-elmasi [Erişim Tarihi: 16.06.2020].

T.C. Tarım ve Orman Bakanlığı. https://www.tarimorman.gov.tr/HAYGEM/KAGEM/Link/1/Ardahan-Balli-Bitkileri [Erişim Tarihi: 24.06.2020].

T.C. Tarım ve Orman Bakanlığı. https://www.tarimorman.gov.tr/SGB/TARYAT/Belgeler/il_yatirim_rehberleri/ardahan.pdf [Erişim Tarihi: 14.06.2020].

Toy, E. (2020). Dijital Çağa Uyumlu Logolar Tasarlamak. Yıldız Journal of Art and Design, 6 (2), 174-189.

Tür, E. (2018). Türkiye ve İsviçre'nin Kış Turizmi Faaliyetleri Açısından Değerlendirilmesine Yönelik Bir Çalışma. Uluslararası Global Turizm Araştırmaları Dergisi, 2 (1), 10-31

Türk Patent Enstitüsü Başkanlı̆̆ https://www.turkpatent.gov.tr/TURKPATENT/resources/temp/A9F54D9E-89D3-4EE9-9C27B28FE3A8BE63.pdf [Erişim Tarihi: 14.06.2020].

Türkiye Kültür $\quad$ Portalı. (2013). https://www.kulturportali.gov.tr/turkiye/ardahan/TurizmAktiviteleri/ardahan-yaban-hayati [Erişim Tarihi: 24.06.2020].

Unur, K. ve Çetin, N. (2017). Kızkalesi'nin Turizm Destinasyonu Olarak Marka Algısı. İşletme ve İktisat Çalışmaları Dergisi, 5 (2), 63-79.

Vizyon Ardahan. (2018). http://www.vizyonardahan.com/kent-profili/ardahan [Erişim Tarihi: 04.07.2020].

Yeni Şafak. (2017). https://www.yenisafak.com/ramazan/kars-ve-ardahanin-vazgecilmezi-kazeti-2722697 [Erişim Tarihi: 12.06.2020]. 
Yenipınar, U. ve Yıldırım, O. (2016). Destinasyon Markalaşmasında Yerel Simgelerin Logo ve Amblemlerde Kullanılması: Muğla Araştırması. Seyahat ve Otel İşletmeciliği Dergisi, 13 (1), 29-45.

Zeybek, B. (2019). Ülke Marka Kişilikleri Üzerine Bir Analiz: “Turkey Home” Kampanyası. Erciyes İletişim Dergisi, 6 (2), 1325-1340. 